\title{
Why is China Better than Indonesia? A Psychological Analysis from the Correlation between Number of Population and Number of COVID-19 Cases
}

\author{
Mengapa China Lebih Baik dari Indonesia? Analisis Psikologis dari Hubungan Jumlah \\ Penduduk dengan Jumlah Kasus COVID-19
}

\author{
Seto Mulyadi ${ }^{1}$, Hendro Prabowo ${ }^{2}$, Mahargyantari Purwani Dewi ${ }^{3}$, Astri Nur Kusumastuti ${ }^{4}$ \\ 1,2,3,4 Universitas Gunadarma, Depok, Indonesia \\ hendroprabowo@gunadarma.ac.id
}

\begin{abstract}
ARTICLE INFO
Article history:

DOI:

10.30595/pssh.v2i.113

Submitted: July 13, 2021

Accepted: Aug 07, 2021

ABSTRACT

This study aims to correlate the population and number of COVID-19 cases in 220 countries in the world. Based on data as of May 2021, the results showed a positive and significant relationship between the number of population and number of COVID-19 cases, with a correlation value of $\mathrm{r}=0.505(\mathrm{p} \leq 0.00)$ and one outlier, which is China which has the highest population in the world $(1,439,323,776$ people) but with the number of cases in the 96th place $(90,799$ cases). Meanwhile, Indonesia has a fourth population $(276,003,941$ people) and has the number of COVID-19 cases in 18th place (1,728,204 cases). This study then discussed why China is better than Indonesia in handling COVID-19 and found that compliance of the citizen and government leadership as the

Published: Sept 24, 2021 psychological factors.
\end{abstract}

This work is licensed under a Creative Commons Attribution 4.0 International License.

Keywords:

Government Leadership, Number of COVID-19 Cases,

Number of Populations,

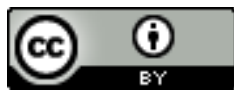

Obedience

Corresponding Author:

Hendro Prabowo

Universitas Gunadarma, Depok, Indonesia

hendroprabowo@gunadarma.ac.id

\section{INTRODUCTION}

Based on data from the Coronavirus cases Report in May 2021, big four of the largest population in the world also have the highest number of COVID-19 cases, namely the United States of America (33,191,361 cases), India (20,237,781 cases), Brazil (14,754,910 cases) and Russia (4,831,744 issues). Exceptions occur in Indonesia and China. Indonesia has a 4th place population $(273,523,615$ people) and has the number of COVID-19 cases in 18th place $(1,686,373$ cases). China, with the largest population globally $(1,439,323,776$ people), has only 96 th place $(90,714$ cases).

The population in China does not affect the number of COVID-19 cases, even though the virus is from that country. The first case was reported on 31 December 2019, when the WHO China Country Office confirmed. There was a new type of virus called coronavirus (novel coronavirus, nCoV) or COVID-19 on 7 January 2020. Initially, on January 11 and 12, 41 cases of COVID-19 were diagnosed in Wuhan City, with symptoms appearing from 8 December 2019 to 2 January 2020 (WHO, 2020).

In Indonesia, the first case of COVID-19 was experienced by two Indonesian citizens living in Depok. The two COVID-19 sufferers, mothers and children, have a history of interacting with Japanese citizens who have previously infected the disease. The first of COVID-19 cases that confirm in Indonesia was announced directly by

Proceedings homepage: https://conferenceproceedings.ump.ac.id/index.php/pssh/issue/view/7 
President Joko Widodo on 3 March 2020 in Jakarta (Indonesia.go.id., 2020).

Shortly, WHO (2021a) reported that in China, from 3 January 2020 to 20 May 2021, there have been 105,330 confirmed cases of COVID-19 with 4,860 deaths. On 13 May 2021, 388,313,603 vaccine doses have been administered. Then, WHO (2021b) also reported that in Indonesia, from 3 January 2020 to 20 May 2021, 1,753,101 confirmed cases of COVID-19 were found, and 48,669 deaths were found. As of 3 May 2021, a total of 22,536,306 doses of vaccine have been administered.

Few studies have tried to link the number of COVID-19 cases to the number of populations. Zarikas, Poulopoulos, Gareiou, and Zervas (2020) found that active grouping cases by population and area help conclude the impact of the disease that is more likely to spread in densely populated areas (countries that have metropolitan with dense population are more vulnerable). Arab-Mazar, Sah, Rabaan, Dhama, and Rodriguez-Morales (2020) found that on 16 March 2020, Iran got 14,991 COVID-19 cases, and mostly from three cities of them Tehran (3,774 cases), Esfahan (1,301 cases), and Qom (1,023 cases). These three cities are large population areas in Iran.

In Indonesia, Sari and Sukestiyarno (2021) find that Cluster 1 or areas with high cases of COVID-19 are DKI Jakarta and West Java provinces; Cluster 2 or areas with middle cases of COVID-19 are Bali, Central Java, and East Java. The five provinces included in cluster 1 and cluster 2 are large population areas in Indonesia. In addition, Notari and Torrieri (2020) found no significant correlation of COVID-19 transmission with the population.

This study aims to test the relationship between the number of COVID-19 cases and the number of people in countries worldwide. In addition, the study also compares the COVID-19 cases in Indonesia and China and discusses the government handling the pandemic from a psychological perspective.

\section{THEORITICAL FRAMEWORK}

Four countries with the largest population globally also have the highest number of COVID-19 cases, namely the United States, India, Brazil, and Russia. Meanwhile, the results of previous studies showed a relation between the number of population and the number of COVID-19 cases such as Zarikas, Poulopoulos, Gareiou, and Zervas (2020), Arab-Mazar, Sah, Rabaan, Dhama and Rodriguez-Morales (2020), and Sari and Sukestiyarno (2021). After statistics tests conducted in 220 countries in the world, we found such a relationship. China is an outlier because it has the largest population globally but has the number of cases of COVID-19 is 96th place in the world. While Indonesia has a 4th place population globally, the number of COVID-19 cases is higher than China or 18th place in the world. Theory X and Theory Y from Douglas McGregor to discuss government leadership and the Stanley Milgram to discuss citizen's obedience, both to compare Indonesia and China in managing the pandemic.

\section{RESEARCH METHODOLOGY}

This research method is quantitative with a cross-sectional research design based on secondary data on the cumulative number of COVID-19 cases in May 2021 and the number of populations at the country level in the world. Secondary data for both variables come from the Coronavirus Cases Report. Descriptive analysis was performed using the Scatter technique and Pearson bivariate correlation analysis. Both were done with the help of SPSS version 20 software. Based on data from the Coronavirus Case Report in May 2021, 222 countries whose citizens were affected by COVID-19. However, two "countries" do not have population data, namely MS Zaandam and Diamond Princess.

\section{RESULTS AND DISCUSSION}

Based on Pearson's correlation analysis, results showed a significant and positive relationship between the number of populations and the number of COVID-19 cases, with a correlation value of $\mathrm{r}=0.505$ ( $\mathrm{p} \leq 0.00)$. It can be said that the higher the number of people, the higher number of COVID-19 instances. On the contrary, the lower the number of people, the lower the number of COVID-19 cases.

Table 1. Correlation

\begin{tabular}{llll}
\hline & & Number of Cases & Number of Population \\
\hline \multirow{3}{*}{ Number of Cases } & Pearson Correlation & 1 & $0.505^{* *}$ \\
& Sig. (2-tailed) & & 0.000 \\
& N & 220 & 220 \\
& Pearson Correlation & $0.505^{* *}$ & 1 \\
Number of Population & Sig. (2-tailed) & 0.000 & \\
& N & 220 & 220 \\
\hline
\end{tabular}

**. Correlation is significant at the 0.01 level (2-tailed).

In addition, based on Scatter analysis, one outlier is China, which has the highest population in the world $(1,439,323,776$ people) but with the number of cases in 96th place (90,799 cases). Meanwhile, Indonesia has a fourth population $(276,003,941$ people) and has the number of COVID-19 cases in 18th place $(1,728,204$ cases $)$. It can also be said that the number of populations in Indonesia who only one-fifth of China have the number of COVID-19 cases is 19 times compared to China. 


\section{Discussion}

Government Policy and Obedience of the Citizen in Indonesia and China

Compliance with social distancing and health protocols can slow or stop the transmission of COVID-19 in Indonesia (Abdy, Side, Annas, Nur \& Sanusi, 2021). Initially, obedience was an experimental analysis by Stanley Milgram about individuals' willingness to obey the orders of an authority (Milgram, 1963). Obedience can be defined as a behavior in compliance with a direct command, frequently issued by an individual in a position of authority (VandenBos, 2007).

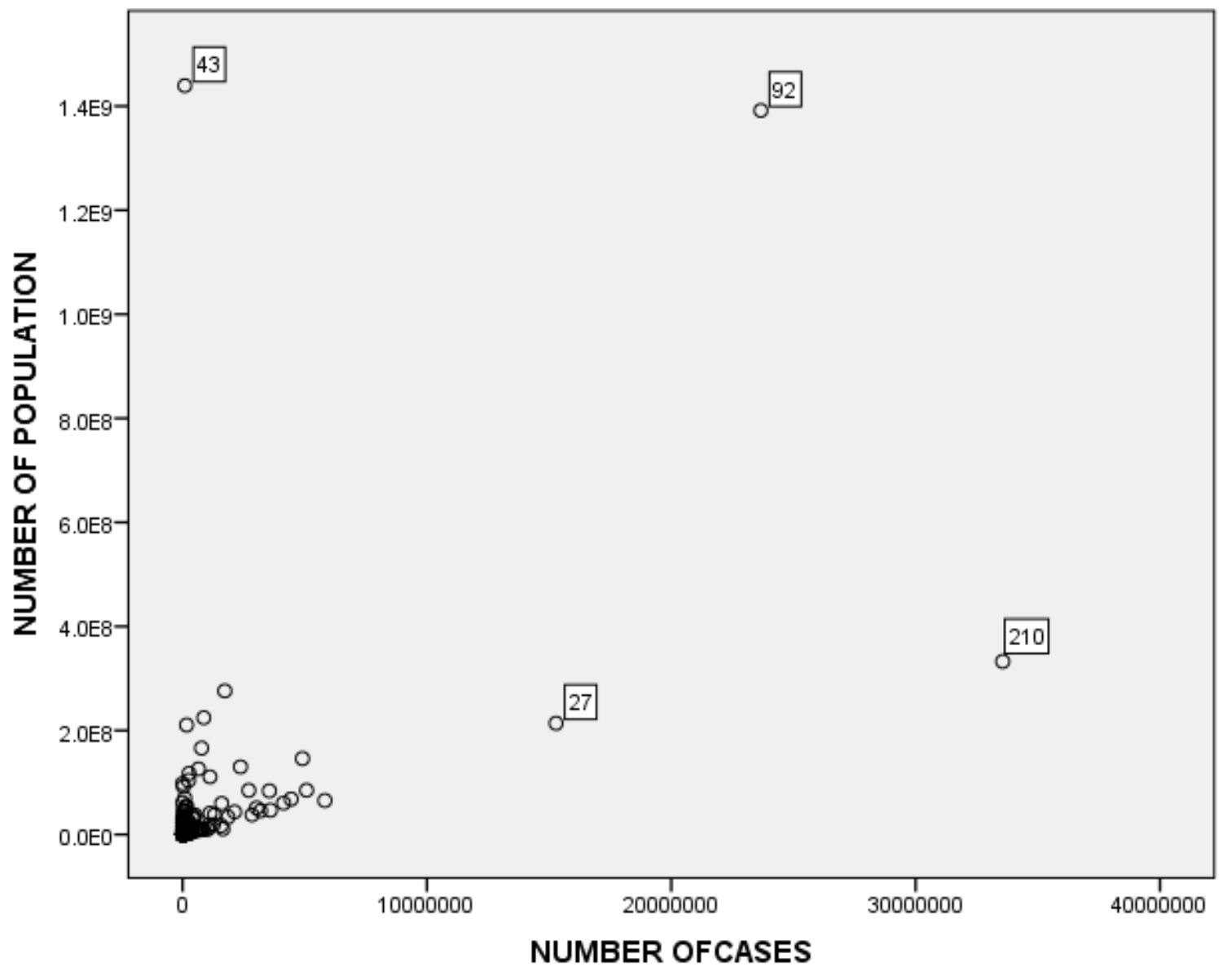

Figure 1. Scatters of the data (no. 43 in China as an outlier)

In Indonesia, many people violate government policy's social restrictions, like social distancing and health protocol (Gedela, Januraga, Luis, Wignall \& Irwanto, 2020). Research in Bandung city, the community still conducts many activities, as usual, the interactions between the individuals do not obey the social distance and even without a mask. This violation is because of livelihood demands, including motorcycle taxi drivers, traditional market traders, and other informal workers (Herdiana, 2020; Delfirman, Erwinsyah \& As'adhanayadi, 2020; Kusuma, 2021). The research results of the Kemenkes RI found only about $42 \%$ of people wash their hands properly. Only 54\% of respondents maintain physical distance in public places (Tim Mitigasi Dokter dalam Pandemi COVID-19, 2020).

Indonesia has a policy implementing social distancing, stay at home, hygiene policies, and country lockdown strategies. Indonesia also closed its borders to foreigners and has recently restricted the travel of all residents between provinces (Gedela et al., 2020). But, Aswicahyono's research shows that during the COVID-19 crisis, the mobility of the population in Indonesia (Facebook users as proxies) is still relatively high. This high mobility occurs especially in major cities in Java and Sumatra. This is because Java and Sumatra are relatively densely populated compared to other regions. Geographical conditions, the distance between regions, limited transportation infrastructure, and low population density outside Java and Sumatra are quite limiting the mobility of residents in these areas (Aswicahyono, 2020). In addition, Kusuma (2021) found sanctions imposed on individuals are verbal or written reprimand, social work by cleaning public facilities, administrative fines of Rp100,000.00, and confiscation of Identify Card.

In China, there are several policies for community-based pandemic prevention and control, including 1) controlling access for residents in both urban and rural areas; 2) control transportation, for example, the entry of cars in other areas is strictly restricted and even prohibited in specific areas; 3) Restricting people from gathering in public places, such as cinemas, mahjong clubs, amusement parks; 4) disinfection of all buildings, and roads daily; 
and 5) the government ensures that the population has sufficient food supplies (Zhang, Zhao \& Hu, 2020). Ren (2020) added that for regions that requested lockdown, local governments apply mandates without interpretation. Lockdown is also used as a local Chinese word, fengcheng (封城), which means to seal a town. Local governments shut air terminals, interstates, and rail line stations, shut most organizations, suspended public vehicle (subways, buses, and taxis), restricted private vehicles, and requested everybody not to leave their apartments except for health-related crises.

Besides the governance policy, the established social culture of moral obedience additionally assumed a significant part inside the control to the COVID-19 (Wang, Yan \& Boasson, 2020), and this mix "policy" is consistent and effective (Mei, 2020). The traditional culture fits authority and social principles and adjusts to good public norms. The residents additionally utilized a trademark "remaining gathering is battling against COVID-19, remaining gathering is your commitment to the nation" to direct individuals on a moral level. Then, 1.4 billion individuals were persuaded and initiated self-isolate separated from clinical staff and other local area laborers. The residents even empowered and regulated each other to follow the isolate prerequisite and battle against COVID-19 together. The activity was carried out in both metropolitan regions (like Shanghai and Beijing) and the far-off or rural areas (like Tibet and Xinjiang). At the same time, all Chinese individuals effectively joined the crisis of the executives against the outbreak. They helped their children gathering to check online as per the government's prerequisites. They conveyed supplies to remain emergency clinics and the networks. These individuals advanced numerous gallant stories during the battle against COVID-19. The public and local media likewise detailed these accounts, and afterward, individuals were persuaded and supported much more (Wang, Yan \& Boasson, 2020).

Government policy has clear penalties for residents who do not obey the policy. For example, if a patient is diagnosed with COVID19 positive, refuses to be isolated, or leaves the isolation area, enters a public place, or takes public transportation, they will be punished with the crime of "willfully violating public safety in a dangerous situation." This punishment also applies to suspected patients because their behavior is the same as the previous patient, thus triggering the spread of the virus. Suppose a person is seriously injured, killed, or causes damage to public or private property. In that case, the defendant will be sentenced to ten years in prison, life imprisonment, or the death penalty. However, if the crime is minor, the defendant will be sentenced to three to seven years in prison (Li, Hu \& Liu, 2020).

Government policies, including law enforcement during the pandemic, China is unique in its political system and culture that makes obedience from its citizens, including extreme measures (The Lancet, 2020; Wang, Yan \& Boasson, 2020). The Chinese compliance with preventive measures is the most effective way to stop the virus before drug treatment or developing and verifying a vaccine. Therefore, by taking preventative measures, Chinese obedience has played a crucial role in preventing the spread of COVID19 in China (Zhao \& Wu, 2020).

\section{Leadership in Indonesia and China}

Democratic countries react more slowly than autocracy countries to the pandemic, and the most solid democratic countries are precisely very slow to respond, although the reaction is very heterogeneous (Cheibub, Hong, \& Przeworski, 2020). As a democratic country, Indonesia's response to this pandemic has lower coercive power than other autocracy countries (Mietmer, 2020), even considered a failure at the beginning of the pandemic (Meckelburg \& Bal, 2020). Strong protection of democratic principles has been established in the "normal" era, making the government less willing to choose restrictive policies to deal with the outbreak (Engler, Brunner, Loviat, Abou-Chadi, Leemann, Glaser \& Kübler, 2021). At various levels of government in Indonesia, a pandemic response varies considerably, including differences that lead to conflicts between central and local governments and between local governments. Similar clashes also occur in countries like the United States, Australia, India, and Thailand (Meckelburg \& Bal, 2020).

China's response to COVID19 is an authorization strategy involving coercive force based on the authority and social consensus. This has been officially announced in China since the beginning of the pandemic, and China has taken political interventions to reduce the pandemic and prevent the virus from persisting in the entire population (Kraemer et al., 2020). In addition to the lockdown measures implemented in Wuhan on 23 January 2020, as of 26 January 2020, 30 provinces have directly responded to public health emergencies. The Chinese authorities and President Xi Jinping declared war at the national level. They called for the use of war narratives to mobilize the public and emphasize the unity of various groups to curb the spread of COVID19. Under China's strict policies, the Chinese are willing to surrender to the authorities. Individuals under a centralized system must abide by this policy of intervention.

The authoritarian leadership in Chinese is more effective than in Indonesia during the pandemics with high obedience. Authoritarian or autocratic is a political system that restricts individual freedom and subjugates individuals to centralized, hierarchical authority. Authoritarian leaders are also called autocratic leaders. They are the type of leaders who determine policies and decision-making without seeking input from citizens, reject suggestions from others, assign tasks to people regardless of their preferences, and dominate interactions through frequent criticism. Instead, Democratic leaders are leaders who establish and maintain an egalitarian group climate in which citizens participate in planning activities, solving problems, and making important choices for the group. Groups with democratic leaders tend to exhibit more incredible originality, higher morals, and less anxiety, aggression, and apathy (VandenBos, 2007). According to Northouse (2021), coercive power involves the use of 
force to influence change. Here, coercion means controlling citizens to do something for their purposes and may include manipulating penalties and rewards on the territory. Douglas McGregor (cite in Lussier \& Achua, 2015) classified attitudes or belief systems into Theory X and Theory Y. Citizens with Theory X attitudes were disliked working and must be closely supervised by the leader.

Conversely, citizens with Theory Y were like to work and did not need to be closely supervised by a leader. Meanwhile, the leader with Theory $\mathrm{X}$ tends to have a negative, pessimistic view of citizens and display more coercive, autocratic leadership styles using external means of control, such as threats and punishment. The leader with Theory $\mathrm{Y}$ attitudes tends to have a positive, optimistic view of citizens and display more participative leadership styles using internal motivation and rewards.

\section{CONCLUSION}

The study concluded a significant correlation between the number of COVID-19 cases and the number of populations in 220 countries worldwide. There is also an outlier that China has the largest population globally but has a relatively small number of cases. By comparing Indonesia and China in its policy of overcoming pandemics, two psychological factors can be concluded: the leadership and obedience of citizens. China has authoritarian leadership obeyed by its citizens, while Indonesia has democratic leadership that its citizens do not strictly follow.

\section{REFERENCES}

Abdy, M., Side, S., Annas, S., Nur, W., \& Sanusi, W. (2021). An SIR epidemic model for COVID-19 spread with fuzzy parameter: the case of Indonesia. Advances in Difference Equations, 2021(1), 1-17. doi: https://doi.org/10.1186/s13662-021-03263-6.

Arab-Mazar, Z., Sah, R., Rabaan, A. A., Dhama, K., \& Rodriguez-Morales, A. J. (2020). Mapping the incidence of the COVID-19 hotspot in Iran-Implications for Travellers. Travel Medicine and Infectious Disease. DOI: 10.1016/j.tmaid.2020.101630

Aswicahyono H. Keharusan menekan mobilitas penduduk untuk mendatarkan kurva epidemiologi covid-19: bukti awal dari data facebook disease prevention map. [Online]. 2020 [cite 2020 April 15]. Available from: https://csis.or.id/publications/keharusan-menekan-mobilitas-penduduk-untuk-mendatarkan-kurvaepidemiologi-covid-19-bukti-awal-dari-data-facebook-disease-prevention-map

Cheibub, J. A., Hong, J. Y. J., \& Przeworski, A. (2020). Rights and deaths: Government reactions to the pandemic. Available at SSRN 3645410. doi: http://dx.doi.org/10.2139/ssrn.3645410

Delfirman, Erwinsyah, R. G., \& As'adhanayadi, B. (2020). Sikap dan persepsi masyarakat berpendapatan rendah terhadap imbauan jaga jarak. Jakarta: Kementerian Sosial Republik Indonesia.

Engler, S., Brunner, P., Loviat, R., Abou-Chadi, T., Leemann, L., Glaser, A., \& Kübler, D. (2021). Democracy in times of the pandemic: explaining the variation of COVID-19 policies across European democracies. West European Politics, 1-22. DOI: 10.1080/01402382.2021.1900669

Gedela, K., Januraga, P. P., Luis, H., Wignall, F. S., \& Irwanto, I. (2020). COVID-19 Lockdown in Indonesia: Greater investment will be needed to mitigate people living with HIV. Asia Pacific Journal of Public Health, doi: 1010539520962611.

Herdiana, D. (2020). Social distancing: Indonesian Policy Reponse to the Corona Virus Disease 2019 (COVID-19). Jurnal Ilmu Administrasi: Media Pengembangan Ilmu dan Praktek Administrasi, 17(1), 93-110. doi: https://doi.org/10.31113/jia.v17i1.555

Ikatan Dokter Indonesia Tim Mitigasi Dokter dalam Pandemi COVID-19. Standar perlindungan dokter di era covid-19. [Online]. $2020 \quad$ [cite 2020 Augst 31]. Available from: https://www.pdspatklin.or.id/assets/files/pdspatklin_2020_09_09_18_05_48.pdf.

Indonesia.go.id. (2020). Kasus COVID-19 pertama, masyarakat jangan panik. https://indonesia.go.id/narasi/indonesiadalam-angka/ekonomi/kasus-covid-19-pertama-masyarakat-jangan-panik

Kavanagh, M. M., \& Singh, R. (2020). Democracy, capacity, and coercion in pandemic response: COVID-19 in comparative political perspective. Journal of Health Politics, Policy, and Law, 45(6), 997-1012. doi:https://doi.org/10.1215/03616878-8641530

Kraemer, M. U. G., Yang, C.-H., Gutierrez, B., Wu, C.-H., Klein, B., Pigott, D. M., . . Scarpino, S. V. (2020). The effect of human mobility and control measures on the COVID-19 epidemic in China. Science, 368(6490),493497.doi:https://doi.org/10.1126/science.abb4218

Kusuma, E. D. (2021). Penerapan sanksi pelanggar physical distancing dan penggunaan masker berdasarkan perwali batu nomor 78 tahun 2020. Dinamika: Jurnal Ilmiah Ilmu Hukum, 27(6), 876-889.

Li, H., Hu, M., \& Liu, S. (2020). The need to improve the laws and regulations relevant to the outbreak of COVID-19: What might be learned from China?. Journal of global health, 10(1). doi:https://doi.org/10.7189/jogh.10.010328

Lussier, R. N., \& Achua, C. F. (2015). Leadership: Theory, application, \& skill development. Mason: Cengage learning.

Meckelburg, R., \& Bal, C. (2020). As COVID-19 escalates in Indonesia, responses are fractured and fractious. Melbourne Asia Review, 5. doi: 10.37839/MAR2652-550X4.5. https://melbourneasiareview.edu.au/as-covid-19-escalates-in-indonesia-responses-are-fractured-and-fractious/

Mei, C. (2020). Policy style, consistency, and the effectiveness of the policy mix in China's fight against COVID- 
19. Policy and Society, 39(3), 309-325. doi:https://doi.org/10.1080/14494035.2020.1787627

Mietmer, M. (2020). Economic capacity, regime type, or policy decisions? Indonesia's struggle with COVID19. Taiwan Journal of Democracy, 16(2).

Milgram, S. (1963). Behavioral study of obedience. The Journal of Abnormal and Social Psychology, 67(4), 371. doi: https://doi.org/10.1037/h0040525

Northouse, P. G. (2021). Leadership: Theory and practice. New York: Sage Publications.

Notari A, \& Torrieri, G. (2020). Covid-19 transmission risk factors. [Online]. [cite 2020 May 12]. Available from: https://www.medrxiv.org/content/10.1101/2020.05.08.20095083v1.full.pdf

Ren, X. (2020). Pandemic and lockdown: a territorial approach to COVID-19 in China, Italy and the United States. Eurasian Geography and Economics, 61(4-5), 423-434. https://doi.org/10.1080/15387216.2020.1762103

Report coronavirus cases. [Online]. 2021 [cite 2021 May 03]. Available from: https://www.worldometers.info/coronavirus/

Sari, D. N. P., \& Sukestiyarno, Y. L. (2021, February). Analisis cluster dengan metode K-Means pada persebaran kasus COVID-19 berdasarkan Provinsi di Indonesia. PRISMA, Prosiding Seminar Nasional Matematika (Vol. 4, pp. 602-610).

The Lancet. (2020). COVID-19: too little, too late?. Lancet (London, England), 395(10226), 755. DOI: 10.1016/S01406736(20)30522-5

VandenBos, G. R. (2007). APA dictionary of psychology. Washington: American Psychological Association.

Wang, L., Yan, B., \& Boasson, V. (2020). A national fight against COVID-19: lessons and experiences from China. Australian and New Zealand journal of public health,44(6), 502-507. doi: https://doi.org/10.1111/1753-6405.13042

WHO. (2020). Novel Coronavirus - China Disease outbreak news: Update 12 January 2020. https://www.who.int/csr/don/12-january-2020-novel-coronavirus-china/en/

WHO. (2021a). Global - China. https://covid19.who.int/region/wpro/country/cn

WHO. (2021b). Global - Indonesia. https://covid19.who.int/region/searo/country/id

Yan, B., Zhang, X., Wu, L., Zhu, H., \& Chen, B. (2020). Why do countries respond differently to COVID-19? A comparative study of Sweden, China, France, and Japan. The American Review of Public Administration, 50(67), 762-769. doi: https://doi.org/10.1177/0275074020942445

Zarikas, V., Poulopoulos, S. G., Gareiou, Z., \& Zervas, E. (2020). Clustering analysis of countries using the COVID-19 cases dataset. Data in brief, 31, 105787. doi: https://doi.org/10.1016/j.dib.2020.105787

Zhang, Y., Zhao, Q., \& Hu, B. (2020). Community-based prevention and control of COVID-19: Experience from China. American journal of infection control, 48(6), 716-717. doi: https://doi.org/10.1016/j.ajic.2020.03.012

Zhao, T., \& Wu, Z. (2020). Citizen-State collaboration in combating COVID-19 in China: Experiences and lessons from the perspective of co-production. The American Review of Public Administration, 50(6-7), 777-783. doi: https://doi.org/10.1177/0275074020942455 